\title{
Az orvos-beteg kommunikáció csapdái daganatos betegség esetén
}

\author{
Muszbek Katalin dr. - Gaal Ilona
}

Magyar Hospice Alapítvány, Budapest

\begin{abstract}
Orvos és beteg között kommunikációs szempontból nyelvzavar áll fenn, amely gátat szab egymás megértésének. A daganatos betegség - fenyegető és krónikus volta miatt - kidomborítja a kommunikációs nehézségeket, felerősíti a kapcsolat jelentőségét. Minden nyelvzavar csak úgy oldható fel, ha megértjük a másik fél motivációit és helyzetét. Célunk az, hogy ennek érdekében az orvosokat hozzásegítsük a beteg, a betegséggel terhelt állapot kommunikációs szempontból lényeges jellemzőinek megismeréséhez. Mélyinterjúkat készítettünk érintett laikusokkal és szakemberekkel, hogy kirajzolódjanak a tipikus kommunikációs zavarok. Jellemzően akkor keletkezik kommunikációs vákuum, amikor a beteg - és ezáltal az orvos - számára is súlyos híreket kell közölni. A beteg számára pszichésen megterhelő a rossz hírek befogadása, az orvosnak pedig aránytalan kihívás, hogy minél kisebb lelki fájdalmat okozzon a páciensnek, miközben saját lelki tartalmaira sem áll módjában tekintettel lenni. Az orvos ezt a nehézséget csak úgy csökkentheti a kiégés veszélye nélkül, ha ismeri a pszichés jellemzőket, amelyek a befogadó felől gátat szabnak a hatékony kommunikációnak. Orv. Hetil., 2016, 157(17), 649-653.
\end{abstract}

Kulcsszavak: orvosi kommunikáció, orvos-beteg kapcsolat, pszichoonkológia, rossz hír közlése

\section{Pitfalls within the cancer-related doctor-patient communication}

There is a "confusion of tongues" in the communication between patient and physician that hinders mutual understanding. Cancer - because of its malignant and often chronic nature - accentuates the communication problems and emphasizes the importance of human relationship. The confusion of tongues can only be resolved through understanding of the situation and motivations of the other person. Thus our aim is to help medical doctors to recognize and understand the most important communication characteristics of the doctor-patient interactions that are strained by the burden of cancer. Interviews with directly concerned professionals and non-professionals were recorded in order to reveal the most common communication disturbances. The majority of the "communication vacuum" arose when bad news should be disclosed for the patient, as bad news is bad for the physician as well. It is emotionally burdening to perceive bad news, and a big challenge for the physician to break it gently, to be tactful, while he/ she has no possibility to pay attention with regard to his/her own emotional stability. Medical doctors can cope with this challenge if they are acquainted with the psychological difficulties of the patients that block the effective medical communication.

Keywords: medical communication, doctor-patient relation, psychooncology, breaking bad news

Muszbek, K., Gaal, I. [Pitfalls within the cancer-related doctor-patient communication]. Orv. Hetil., 2016, 157(17), 649-653.

(Beérkezett: 2016. február 26.; elfogadva: 2016. március 17.)

Hatékony betegellátás nem képzelhető el megfelelő orvos-beteg kapcsolat nélkül, amelyben a beteg úgy érzi, megkapta a szükséges magas szintű ellátást és odafigyelést, az orvos pedig hasznosnak és emberségesnek érezheti magát. A gyakorlatban azonban nem teljesül mindkét szempont, és ennek leggyakoribb oka a nem megfelelő kommunikáció. Jaspars és mtsai kimutatták, hogy a jó orvos-beteg kapcsolatról megkérdezett betegek 72\%-ban inkább a pszichológiai és kapcsolati elemeket helyezik előtérbe, mint a szorosan vett orvosi-technikai tényezóket [1]. A beteg azzal keresi fel az orvost, hogy panaszai vannak, és - bár szeretné hinni, hogy csak 
banális betegség húzódik meg tünetei hátterében - tudni szeretné, mi a betegsége és milyen kezelések várhatók. A kiszolgáltatott helyzetnek megfelelően fél az orvosától, igényelne egy emberi kapcsolatot, de tudja, hogy a speciális helyzet miatt erre kevés az esélye. Az orvosok a szakma szabályai szerint látják el a betegeket, a hangsúlyt a diagnózisra és a terápiás javaslatra teszik. Ez a séma orvos és beteg viszonyára a kettejük közti nyelvzavart tükrözi. A nyelvzavar Ferenczi Sándor találó és sokat alkalmazott kifejezése, ő arra a helyzetre dolgozta ki, amikor a gyermek a felnőtt mindenféle, akár rossz szándékú közeledését (nem „beszélve” a felnőttek nyelvét, nem értve a felnőttek motivációit) félreértelmezi és szeretetnek fordítja le [2]. Az orvos-beteg viszony jellemzésére azért alkalmas ez a kifejezés, mert itt is arról van szó, hogy a két fél eredendően nem érti egymást. Az orvos társadalmi megbízatása betegségekre vonatkozik, e szempont szerint osztják fel a tantárgyakat, e mentén szerveződnek a kórházi osztályok. Valójában az egyetemi képzés a „mindent tudni, mindenkit meggyógyítani” szemlélet jegyében zajlik, és elsősorban a szomatikus rendszerre fókuszál. Elhanyagolt része a graduális és posztgraduális képzésnek a kommunikáció, a rossz hír közlése, ami miatt az orvosok frusztráltak a nehéz beteggel, a nehéz orvos-beteg kapcsolatban. Az orvos nem tud megfelelni a társadalmi elvárásoknak, az idealizált orvosszerepnek, a beteg pedig úgy érzi, magára hagyták, és az információk hiányában szorongása fokozódik. Ez a nyelvzavar elkerülhető, vagy legalábbis jelentősen csökkenthető, ha a felek jobban értik a másikat, viselkedését, motivációit. Az alábbiakban a nyelvzavar csökkentéséhez kívánunk hozzájárulni, konkrét történetek elemzésével. Történeteink forrása az a mélyinterjús kutatás, amelynek során összesen 16 interjúalannyal ( 5 beteg, 3 ápoló, 6 orvos, 1 hozzátartozó, 1 betegklubvezető) beszélgettünk, egyenként 1-3 órát. A szakemberek onkológiai osztályok munkatársai, a beteg és hozzátartozó interjúalanyaink daganatos megbetegedésben érintettek. (Az interjúalanyok álnéven szerepelnek [3].)

Mária 64 éves, gyomor-és hasi panaszokkal fordult háziorvosáboz, s igy derült ki magas vörösvértest-süllyedése. Az 50 fölötti süllyedéssel többször megjelent a rendelésen, $s$ jelezte, hogy néha van epekóproblémája, de egyébként jól van. Az ultrahangvizsgálat során rendellenességet észleltek, MR-vizsgálatra küldték, abol béldaganatot diagnosztizáltak májáttéttel. „Ezt a leletet megmutattam a lányomnak, aki ápolónó, és elsápadt, amikor elolvasta. A szomszédasszonyom asszisztens, "o" is megnézte és nagyon elkomorult. A háziorvosom felcsattant, hogy nem "o a hibás, én vagyok a hibás, mert nem mentem idöben. Pedig az elmúlt fél évben négyszer is voltam laborvizsgálaton.”

Gabriella 52 évesen rendszeresen járt ellenörzésre pajzsmirigybetegsége miatt, s többször állapitottak meg magas süllyedést, majd hematológiára küldték kivizsgálásra. A leletek alapján azt közölték vele, hogy nincs hematológiai betegsége, idönként jelenjen meg kontrollon. Ezután immunológushoz járt, ahol vért vettek, de nem mondtak sem- mit a betegségéről. „Egyszer az orvos megkérdezte, hogy tudok-e arról, milyen fehérje-rendellenessége volt az apukámnak. Emlékszem, akkor átsuhant az agyamon, hogy ez a kérdés nem jelenthet jót. De az orvos erröl sem mondott semmit, én pedig nem kérdeztem. Nem mondtak semmit arról, mi lehet a bajom, a kezembe nyomtak egy cetlit, amire az volt ráirva: Waldenström-macroglobulinaemia. Erröl sohasem hallottam...”

Mindkét esetben a betegek hosszabb időn keresztül vettek részt laborvizsgálatokon, de enyhe fizikai tüneteik miatt elfogadták orvosuk rendszeres kontrollvizsgálati javaslatát, nem forszírozták a részletesebb kivizsgálást. Az orvosok kényelmetlenül érezték magukat, amikor kiderült, hogy malignus betegség áll a tünetek hátterében. Az első esetben a háziorvos saját frusztráltságát a betegre vetítette, őt hibáztatta a késői diagnózisért. Itt tetten érhető az orvosi „apostoli funkció” gyakorlása, amint ezt Bálint Mihály megfogalmazta: Mintha minden orvosnak lenne egy határozottan megfogalmazott, szilárd elképzelése arról, hogy mi a jó és mi a rossz a betegnek, s ez befolyásolja az orvos munkájának minden aspektusát [4]. Pedig előtérbe lehetne helyezni az „orvos is ember” tényezőt, és azt mondani: „Nagyon sajnálom, hogy sok idő telt el, de annyira nem voltak panaszai, nem akartam kitenni önt felesleges vizsgálatoknak.” Ez az emberi hangvétel jelentősen enyhítette volna a beteg kétségbeesését, hiszen onkológiai osztályra utalták, ami számára egyenlő volt akkor a halálos ítélettel.

A második esetben is magára maradt a beteg, hiszen elmaradt a megfelelő betegtájékoztatás. Orvosai mindig csak a következő kontrollvizsgálatra hívták fel a figyelmet, ezt várva még érthető az alulinformálás. Nincs verbális kommunikáció a beteggel, és az orvos részéről nem mutatkozik nyitottság, arra utaló magatartás, hogy biztassa betegét kérdésfeltevésre. Söt a szóbeli beszélgetés helyett egy papíron átadott diagnózissal tudja le a betegtájékoztatást. Az orvos valószínúleg kényelmetlenül érezte magát, nem tudta, milyen formában tájékoztassa betegét, nem tanulta meg, hogyan lehet egy rossz hírt közölni, így a legrosszabb megoldást választotta.

Első idézett interjúalanyunk, Mária keserves tapasztalatokat szerzett nemcsak betegsége inadekvát ellátásával, hanem a kórházban az orvosi kapcsolat hiányával, ridegségével. Az orvos viszonya betegeihez nemcsak szavakban fejeződik ki, hanem metakommunikációval, testtartással, hanghordozással, gesztusokkal, mimikával. Jelen esetben mind a verbális, mind a nonverbális kommunikáció azt fejezte ki, hogy az orvosok részvétlenek a beteggel, már-már a kiégés jeleit mutatják, végső kétségbeesésbe taszítva a beteget [5].

„Kórházba kerültem, abol az orvos azt mondta, annyira le vagyok gyengülve, hogy nem lehet hozzám nyúlni. Egy fóorvosnó vizsgált meg, barátságos volt, de nem igazán foglalkozott velem, átadott az osztályos orvosoknak. Volt két fiatal doktor, akik ridegek, érzéketlenek voltak. Bejöttek, közölték, hogy rákos vagyok, nem tudnak mit csinálni, nem tudnak segiteni, mert olyan stádiumban vagyok. Jöttek vi- 
zitelni, de egyszer sem kérdezték meg, hogy érzem magam, még csak egy kedves mosoly sem volt. Az orvosok olyan nagyon merevek voltak. Lehet, hogy nehéz nekik találkozni egy rákossal, megmondani, hogy nincs további kezelés. Később pedig folyamatosan azt kérdezték, hogy mikor megyek már el? Kérdeztem, hogy hova? Azt kérdezték, találtunk-e már helyet, mikor megyek haza. Én csak arra gondoltam, hova mehetnék ilyen állapotban?”

Mária esetében paradox módon a hospice-ellátás hozta a megnyugvást. Korábban sehol nem beszéltek vele nyíltan a betegségéről, ő pedig - fejet hajtva az orvosok magatartása előtt - nem erőltette, neki is jelentett ez némi (látszat)könnyebbséget. A hospice-házba, életvégi ellátásra került az amúgy korábban nem kellően felvilágosított beteg, ahol a nyugodt, elfogadó légkörben az életével kapcsolatos rossz híreket békésen, megnyugvással fogadta:

„Elöször a hospice-orvossal tudtam normálisan beszélni a betegségemröl. Tudtam, hogy daganatom van, de nem tudtam az áttétekrôl, és hogy mi lesz velem. A doktornó biztatott, hogy kérdezzek, ha most nem jut eszembe, holnap visszajön és beszélgetünk. Leült, szánt rám idöt, türelmes volt, mosolygott is. Nagyon megnyugtató volt annak ellenére, hogy itt jöttem rá: már nagyon kevés idöm van hátra...”

Közel húsz éve jelent meg az egészségügyi törvény, amely az orvosok részéról kötelességként, a betegek részére jogként fogalmazza meg a betegtájékoztatást [6]. Nagy horderejű változást hozhatott volna a törvény életbe lépése, de a tájékozási kötelezettség alóli felmentő kitételeket az orvosok a gyakorlatban úgy értelmezték, hogy nem a beteggel, hanem elsősorban a családtaggal közölték a diagnózist [7].

Orvos interjúalanyaink arról számolnak be, hogy nagyon egyedül vannak a rossz hír közlésének problémájával. Onkológus beszélgetőpartnerünk a képzés hiányosságaira is kitér e kérdéskör kapcsán: „1989-ben kezdtem dolgozni egy karizmatikus, oktató, régi típusú fóorvos mellett. Ekkor még két zárójelentés volt, a beteg kapott egy úgynevezett spuriumot, amiben nem szerepelt a rák, daganat, rosszindulatú szó, hanem mindenféle góc meg folt. A másikat valódi tartalommal a kezelöorvos kapta. A következó munkabelyemen a föorvos döntötte el, hogy milyen zárójelentést kapjon a beteg. De én már ebben az idöben úgy éreztem, hogy a beteggel személyes kontaktust kell kialakitani, hogy kötödjön valakibez és bizalma legyen. Voltak viták erröl, meg kell-e mondani a betegnek, és hogyan mondjuk meg finoman. Aztán elkezdödött egy nyíltabb kommunikáció - kvázi gyöztünk, de nem tudtuk, jól csináljuk-e, mert nem tanultuk...”

Gabriella kereste annak lehetőségét, hogy többet tudjon meg betegségéról, és az út az internethez vezetett: „Bementem a munkabelyemre, és megnéztem az interneten. Igazából csak arra emlékszem, hogy a Waldenströmmacroglobulinaemia mellett ott volt zárójelben, hogy nonHodgkin-lymphoma és myeloma. Nem tetszett a dolog.
Csak annyit tudtam, hogy non-Hodgkin-lymphomában balt meg Antall József. Tehát az nem jó dolog. Myelomában az apukám halt meg, az sem tünt vonzónak. Így jobbnak láttam kikapcsolni a gépet. A háritást választottam "problémamegoldásnak"." Gabriella azt is olvasta az interneten, hogy „Azén betegségemmel - mert menet közben eltelt nébány év - már csak egy-két évem van hátra. Megrémültem, nagyon kiborultam.”

Ma már az információk széles köre áll rendelkezésre, a betegek, családtagok az internetről tájékozódnak egy szüretlen, laikus tapasztalatokkal és érzelmi torzításokkal tüzdelt, nem utolsósorban pedig hamis, anyagi haszonszerzés reményében kreált információhalmazból. Ez sokkal több veszélyt rejt magában, mint amikor a beteg szemtől szemben beszélheti meg az orvosával, mi is fog történni vele.

A tényekkel szembe nem néző betegek, illetve családtagjaik a szükségszerünél is nehezebb sorsot vesznek magukra, amikor az elérhetetlen gyógyulást keresve elmennek a tünetek enyhítésének, az életminőség javításának reális lehetőségei mellett. Nem veszik igénybe a palliatív ellátás életminőséget javító módszereit, elutasítják az adekvát fájdalomcsillapítást. Kellő információk hiányában számukra az aktív kezelés az egyetlen választható út $[8,9]$. Ugyanakkor az internet mindenképp segíti a betegeket abban, hogy kérdezni merjenek, hiszen mindannyian olvastak a betegségükról a neten, nyilván találtak ellentmondásos vagy ijesztő információkat, amelyek erősítik abbéli igényeiket, hogy kételyeiket, kérdéseiket megosszák orvosaikkal. Nagyon megkönnyíti az orvos helyzetét, ráadásul hosszabb távon csökkenti a kiégés esélyét, ha valódi kapcsolatot teremt páciensével, amelyben a beteg is feloldódik. Ehhez persze szükség van egy nyitott orvosra és egy érdeklődő betegre. Az alábbi példa azt mutatja, hogy együttmúködő kapcsolatban hogyan segít a korrekt tájékoztatás: „Behivatott a doktorno", és ahogy ült le mellém az asztalhoz, már láttam, hogy baj van. Semleges próbált maradni, nem dramatizált, de nem is pátyolgatott. "Megvan az evedmény - mondta -, sajnos ez egy rosszindulatú elváltozás. "Nekem ez nagyon nehéz volt, el is sirtam magam. De utána rögtön arra koncentráltam, már az volt a következó kérdésem, hogy jó, most ezt tudjuk, de mi a következölépés, mit kell tennem? A doktornö elmondta, hogy kicsi az elváltozás, operálni kell, utána jöhet a többi kezelés, de errôl késöbb beszéljünk... Érdekes volt számomra, mert mielött ebbe a belyzetbe kerïltem, azt gondoltam, hogy ha kapnék egy ilyen hirt, teljesen összeomlanék. Ez persze a hír hallatán meg is történt, de a doktorno" sokat segitett, hogy ilyen határozottan, céltudatosan végig tudtam csinálni."

Az orvos-beteg kapcsolatot jelentősen befolyásolja, hogy a betegek milyen módon viszonyulnak az állapotukhoz. Az emberi természettel összefügg az a mágikus gondolkodás is, hogy negatív dolgokra azért nem szabad gondolni, mert azzal „bevonzzuk” a rosszat [10]. Ennek az ezoterikus gondolatnak egyenes következményeként 
mind a beteg, mind a hozzátartozó súlyos bűntudatot élhet át, amikor a gyógyíthatatlanságra, a halál lehetőségére gondol, hiszen növeli a szorongást, fokozza a szenvedést, ha valaki azt hiszi, hogy „rossz” gondolataival maga okozza azt, amit kétségbeesetten szeretne elkerülni [11].

A rákbetegeknél a diagnózis pillanatától jelen van a szorongás, a végzetes betegséggel való szembenézés nagy pszichés teher a betegnek. Muszbek és mtsai kutatásából kiderül, hogy mind a szorongás, mind a depresszió magas előfordulása jellemző a rákbetegekre, sőt mindkét pszichológiai jelenség és tünete szignifikánsan magasabb a nemzetközi átlagnál [12].

Ezzel összefügghet a tagadás jelensége: amikor a beteget tájékoztatják egy életet fenyegető betegség diagnózisáról, gyakran érzékelhető első reakció a tagadás. Elisabeth Kübler-Ross írja le a tagadás jelenségét, mint jellegzetes pszichés reakciómódot [13]. A beteg félreértelmezi az orvosi közlést, nem tudja elhinni, hogy egy életet fenyegető betegséggel találkozik. „Biztosan tévedésről van szó.” „Talán elcserélték a leletet!” „Próbálkozom egy másik orvosnál...” - ezekhez hasonló gondolatok fordulnak meg a fejekben. Szinte lebénul a beszélgetésben, hallja, de nem érti az orvost, nem tesz fel kérdéseket. A már idézett Gabriella így foglalja össze saját magatartását: „Bizonytalan voltam. Nyilván bennem is volt háritás, soha nem kérdeztem rá, nem erôltettem. Az én saram is volt ez. Rossz érzés volt, nagyfokú bizonytalanság, mert a lelkem mélyén tudtam, hogy valami baj van.”

A rossz hír hallatán a betegeknél gyakori a lelki összeomlás és a tudattalan elhárító mechanizmus. Egyik interjúalanyunk erre így emlékszik: „Vannak dolgok, amikre nem emlékeztem, elfelejtettem, mit mondott a doktornö. Annyira sok minden zudul ilyenkor az emberre, rengeteg információ, és az a lelkiállapot, amibe keriul az ember, kicsit elbomályositotta az emlékeimet. Olyan dolgokra emlékszem inkább, amelyek nagyon fontosak voltak. Kicsit szégyelltem magam, hogy késöbb több dologra rá kellett kérdezni, amiröl már beszélt a doktornö...”

A kutatások azt mutatják, hogy a diagnózis közléséhez kapcsolódó információk mintegy 40-50\%-át nem tudják felidézni a betegek [14]. Ám a következő orvosi megjelenésnél újra rákérdeznek a már elhangzottakra. Az orvosok emiatt gyakran neheztelnek a betegre, amiért az „visszaél” amúgy is kevés idejükkel. Pedig félreértik a beteget: szó sincs visszaélésről, az adott helyzetben természetes hárítás gátolja az információk befogadását. Ráadásul a betegség olyan pszichés állapotot vált ki, amelyben gyermeki viszonyulásmódok aktiválódnak [15]. A helyzetnek előnye is van az orvos számára, a lépcsőzetes betegtájékoztatás lehetôsége: az ismétlésekkel jobban tud hatni arra, hogy a beteg mit tartson fontosnak, és alkalmat ad újabb ismeretek megosztására. A hárítás jelensége miatt célszerú biztatni a beteget, hogy hozzátar- tozójával jelenjen meg a konzultáción, akivel később együtt tudják felidézni és feldolgozni az elhangzottakat.

Két interjúalanyunk az asszertív csoportba tartozik, azok közé, akik mindent szeretnének tudni a betegségükről, a kezelésről, tájékozottak, kérdéseikkel néha az orvost is nehéz helyzetbe hozzák: „Mindig tartottam az orvos-beteg kapcsolattól, mert azt gondoltam, hogy az orvosok magasabb rangú lények, ezért úgysem fognak annyira segiteni. Nem adnak személyre szabott segitséget. De az eltelt két és fél év alatt kellemesen csalódtam. Ha kérdez az ember, akkor megkapja a választ, de ha nem, akkor nem.”

Imre 65 éves beteg, végbélproblémával, vérzéssel fordult háziorvosához, majd proktológushoz. Hónapokig kezelték aranyérgyanúval, majd amikor elunta, hogy állapota nem javul, otthagyta a szakorvost. „Visszamentem a háziorvoshoz, és elmondtam neki, hogy nem tudtam meg semmit, és nem is történt semmi. A háziorvos megkérdezte, mi a véleményem. Fiatal háziorvosom van, harmincvalahány éves. Az én orvosom azt sem tudta, mi van. Ön szerint mi lehet? - kérdezett vissza a háziorvos. Mondom, nem tudom, de nem néznénk meg az én koromban a vastagbelet vagy a prosztatát? Hát - azt mondja -, nézzük!”

Különleges helyzetet foglal el az orvos-beteg kapcsolatban az intenzív osztály. Az orvost nagymértékben terheli a súlyos beteg tudatának beszúkülése, ami nem teszi lehetővé a verbális kommunikációt. Orvosi szakértői mivoltát ugyan érvényesíti, mégis úgy érzi, hogy szinte fontosabb a pontos adminisztráció az esetleges jogi következmények elkerülése végett. Mindkét tényező az aneszteziológusok kiégésének veszélyét rejti magában. Egyik interjúalanyunk ezt így fogalmazta meg: „Itt alig találkozunk a beteggel, azt is mondhatnám, hogy az orvosbeteg kapcsolat szinte a nullával egyenlö. Ugyanis az intenziven nem a beteggel kommunikálunk, hanem a bozzátartozóval. Minimális a kontaktus. Az intenzív osztályon nagyon fontos az, hogyan kommunikálunk a bozzátartozóval. Azt kell éreztetni, hogy itt jó helyen van a beteg, mindent megtettünk érte, de nem tudtunk segiteni rajta. A legtöbb kollégánk ott követi el a hibát, hogy iszonyuan ki vannak égve és nagyon frusztrálja őket ez a fajta defenziv medicina. Azt érezzük, hogy folyamatosan védekeznünk kell, úgy kell leirnunk mindent, hogy abba ne lehessen belekötni. Hogy a bozzátartozó ne tudjon perelni és ne érezze úgy, hogy egy-két milliót ki tud búzni a kórbázból, abhoz az kell, hogy jól kommunikáljunk vele. És itt jönnek be azok a dolgok, amelyeket tavaly egy kommunikációs képzésen tanultunk, az orvosi kommunikáció alapszabályai: amikor elöször találkozunk a hozzátartozóval, akkor nem a folyosón, nem a beteg mellett, hanem az orvosiban adjunk felvilágositást, mert nyugodt környezetben kell elmondani a dolgokat, nem türelmetlenül. A zsebkendöt, a vizet elókésziteni, és elhitetni vele azt, hogy jó helyen van és nem lesz baj. Ezt nagyon nehéz elérni azoknál a kollégáknál, akik agyon vannak terhelve, frusztráltak, kiégettek.” 


\section{Megbeszélés}

Az interjúrészletekből kirajzolódik, hogy a jó orvos-beteg kapcsolathoz mindkét félre szükség van. Hiába ad pontos diagnózist az orvos, ha a beteg nem hallja meg, amit mond; és csak annál a betegnél lehetséges egy papírcetlivel letudni a diagnózis közlését, aki nem kérdez bár nála sem szabad. Az orvos dolga, hogy a maga részéről mindent megtegyen a jó kapcsolat érdekében. A félreértés lehetősége radikálisan csökken, ha az orvos tudatosítja a kommunikációzavar jelenségeit:

- Ha a beteg nem jegyzi meg azt, amit az orvos fontos mondandónak tart, az orvos ne arra gondoljon, hogy a beteg nem akarta meghallani, hanem arra, hogy a betegséggel való szembesülés és a találkozás az egészségügyi rendszerrel beszúkült tudatállapotot eredményez, amely miatt a beteg nem tudja meghallani azt, amit az orvos pontosan, alaposan elmondott. Ezért a hozzátartozó bevonása az orvosnak is érdeke, még akkor is, ha a hozzátartozó más igénnyel lép fel a tájékoztatást illetően, mint amit az orvos helyesnek tart vagy amit követnie kell.

- Az, hogy a páciensek az interneten utánanéznek a betegségüknek, nem kritika az orvos felé, vagy ha az, akkor megfogalmazódna az internet nélkül is. Az internet felerősíti annak az orvosi attitűdnek a jelentőségét, amely kérdezésre bátorítja a betegeket.

- A beteg és hozzátartozó bevonása a terápiába, a döntésekbe, a hibák elismerése - vagyis a mindenható orvos szerepéről való lemondás - radikálisan csökkenti az orvos nyomasztó felelősségérzetét, és sokkal elviselhetőbbé, megoldhatóbbá teszi a körülményekből fakadó kapcsolati problémákat, nem utolsósorban pedig jogilag is kevésbé támadhatóvá az orvost magát.

Anyagi támogatás: A közlemény megírása anyagi támogatásban nem részesült.

Szerzői munkamegosztás: M. K.: A tanulmány struktúrájának kidolgozása, a szakirodalom feldolgozása, a kézirat megszövegezése. G. I.: A tanulmányban szereplő interjúk elkészítése, a kézirat megszövegezése. A kézirat végleges változatát mindkét szerző elolvasta és jóváhagyta.

Érdekeltségek: A szerzőknek nincsenek érdekeltségeik.

\section{Irodalom}

[1] Jaspars, J., King, J., Pendleton, D.: The consultation: A social psychologycal analysis. In: Pendleton, D., Hasler, D. (eds.): Doctorpatient communication. Academic Press, London, 1990.

[2] Ferenczi, S.: Confusion of tongues between adults and children. In: Ferenczi, S.: Technical writings. [Nyelvzavar a felnőttek és a gyermekek között. In: Ferenczi, S.: Technikai írások.] Animula Kiadó, Budapest, 2006. [Hungarian]

[3] Conversation. [Beszélgetés.] http://www.hospicehaz.hu/orvos-beteg-kapcsolat/beszelgetes. [Hungarian]

[4] Bálint, M.: The doctor, his patient and the illness. Churchill Livingstone, Edinburgh, 1957.

[5] Németh, E.: The nonverbal communication. In: Pilling, J. (ed.): Medical communication. [A nonverbális (nem szóbeli) kommunikáció. In: Pilling, J. (szerk.): Orvosi kommunikáció.] Medicina Könyvkiadó, Budapest, 2008. [Hungarian]

[6] Dósa, Á.: Liability of health care providers. [Az orvos kártérítési felelőssége.] HVG-ORAC. Budapest, 2004. [Hungarian]

[7] Greminger, É.: The effect of the right of information in Hungary. [A tájékoztatáshoz való jog megvalósulása hazánkban.] Nóvér Praxis, 2003, 6(9), 37-44. [Hungarian]

[8] Gunnarsdottir, S., Donovan, H. S., Serlin, R. C., et al.: Patientrelated barriers to pain management: the Barriers Questionnaire II (BQ-II). Pain, 2002, 99(3), 385-396.

[9] Foley, K. M.: How well is cancer pain treated? Palliat. Med., $2011,25(5), 398-401$

[10] Shermer, M.: The (other) secret. Scientific American, 2007, 39, 296.

[11] Varga, K., Lénárt, Á., Biró, E.: Applied affective psychology: mobilizing human resources in special situations. In: Bányai, É., Varga, K. (eds.): Affective psychology. [Alkalmazott affektív pszichológia: emberi erőforrások mozgósítása kitüntetett élethelyzetekben. In: Bányai, É., Varga, K. (szerk.): Affektív pszichológia.] Medicina Könyvkiadó, Budapest, 2013. [Hungarian]

[12] Muszbek, K., Székely, A., Balogh, É. M., et al.: Validation of the Hungarian translation of Hospital Anxiety and Depression Scale. Qual. Life Res., 2006, 15(4), 761-766.

[13] Kübler-Ross, E.: On death and dying. [A halál és a hozzá vezető út.] Gondolat Kiadó, Budapest, 1988. [Hungarian]

[14] Pilling, J. (ed.): [Medical communication. Orvosi kommunikáció.] Medicina Könyvkiadó, Budapest, 2008. [Hungarian]

[15] Buda, B.: The regularity of the common human communication. [A közvetlen emberi kommunikáció szabályszerűségei.] Animula Kiadó, Budapest, 1986. [Hungarian]

(Muszbek Katalin dr., Budapest, Kenyeres u. 18-22., 1032 e-mail: katalin.muszbek@hospicehaz.hu) 